Research Article

\title{
Novel Gallium(III), Germanium(IV), and Hafnium(IV) Folate Complexes and Their Spectroscopic, Thermal Decomposition, Morphological, and Biological Characteristics
}

\author{
Abeer A. El-Habeeb \\ Department of Chemistry, College of Science, Princess Nourah Bint Abdulrahman University, Riyadh 11671, Saudi Arabia \\ Correspondence should be addressed to Abeer A. El-Habeeb; dr_abeer_2@hotmail.com
}

Received 15 October 2020; Accepted 30 November 2020; Published 21 December 2020

Academic Editor: Massimiliano F. Peana

Copyright () 2020 Abeer A. El-Habeeb. This is an open access article distributed under the Creative Commons Attribution License, which permits unrestricted use, distribution, and reproduction in any medium, provided the original work is properly cited.

\begin{abstract}
In this study, we describe novel gallium(III), germanium(IV), and hafnium(IV) folate complexes, including their synthesis and analyses. The synthesized folate complexes were also subject to thermal analysis (TGA) to better examine their thermal degradation and kinetic properties. The folate complexes had high stability and were nonspontaneous. The Coats-Redfern and Horowitz-Metzger equations were used to determine thermodynamic parameters and describe the kinetic properties. These complexes were synthesized through the chemical interactions in neutralized media between the folic acid drug ligand $\left(\mathrm{FAH}_{2}\right)$ with $\mathrm{GaCl}_{3}, \mathrm{GeCl}_{4}$, and $\mathrm{HfCl}_{4}$ metal salts at $1: 2$ (metal : ligand) molar ratio. The conductance measurements have low values due to their nonelectrolytic behavior. The X-ray powder diffraction solid powder pattern revealed a semicrystalline nature. In vitro, we screened the synthesized folate chelates for antibacterial and antifungal activities. The inhibition of four bacterial and two fungi pathogens (E. coli, B. subtilis, P. aeruginosa, S. aureus, A. flavus, and Candida albicans) was improved using a folic acid drug relative to the control drug.
\end{abstract}

\section{Introduction}

Folic acid $\left(\mathrm{FAH}_{2}\right)$ is also referred to as pteroylglutamic acid [N-(4\{[(2-amino-4-oxo-1,4-dihydropteridin-6-yl)methyl] amino\}benzoyl)-L-glutamic acid]. Folic acid is a member of the B9 vitamin family [1]. Folic acid consists of three sections of $p$-aminobenzoic acid (PABA) pteridine ring and glutamic acid moieties (Figure 1). The term folate refers to the deprotonated form of folic acid, which plays an essential role in critical biosynthetic processes in mammalian cells [2]. The folate molecule is made as a coenzyme in the case of DNA, RNA, and protein components synthesized by single carbon transfer reactions [3]. Folate is necessary for the synthesis of methionine, methylation of DNA, histone neurotransmitters, and lipids. The deficiency in folic acid led to DNA strand breaks [4], DNA hypomethylation [5], and abnormal gene expression [6]. Folic acid has a potential anticancer activity in some important cases, such as breast, colorectal, and ovarian carcinomas [7]. The World Health Organization has added folic acid to the list of trusted drugs that are most needed. For humans, this vitamin should be obtained from the diet because the human body cannot produce it. The recommended daily folate intake for adults is $400 \mu \mathrm{g}$ [8]. Folic acid is one of the major molecules for the synthesis of DNA [9]. Folic acid receptors (FRs) have been considered a target to assimilate the organic molecules associated with folic acid in cells. Application of folic acid receptor-targeted molecules is not new; there have been many articles addressing the conjugation of folates to known organic drug molecules, such as taxol, paclitaxel, and doxorubicin, to improve drug targeting [10-13].

However, there is a lack of literature concerning the conjugation of folic acid to metal-based molecules and even less regarding their chemotherapeutic potential. Incorporating simple folate ligands into biologically active metal complex systems might offer a simple strategy for improving 


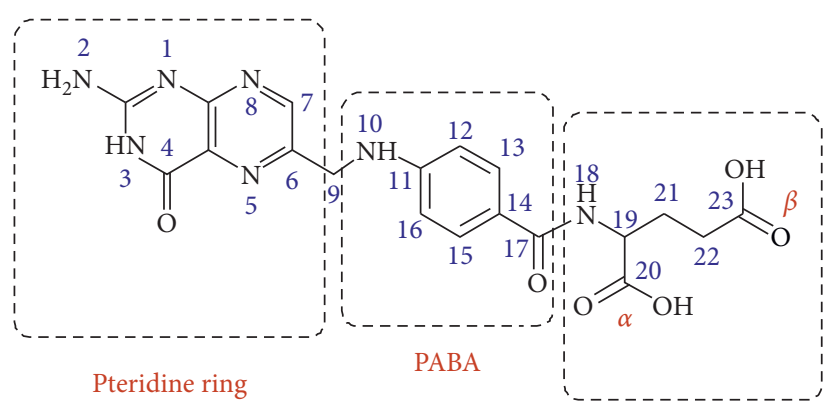

Glutamic acid

Figure 1: Structure of folic acid $\left(\mathrm{FAH}_{2}\right)$.

their selective uptake in FR cells [2]; on the contrary, it was found that the metal complexes of folic acid might provide an advantage by increasing the inhibitory activity of folic acid [7]. Folic acid can form complexes with different metal ions via the pteridine ring or glutamic acid moiety. The pteridine ring binds to metal ions via its nitrogen and oxygen atoms (of a carbonyl or an iminol group) in the coordination process [14]. But this case is not common since the pteridine ring is a highly $\pi$-electron-deficient heterocycle, while glutamic acid forms stable complexes with metal ions [15]. Three types of coordination modes have been mentioned in literature on folic acid: bidentate bridging via $\alpha$ and $\gamma$ carboxylate groups [16-20], tridentate ( $\alpha$ and $\gamma$ carboxylate groups) and the amide nitrogen of the glutamate moiety $[2,21]$, and chelating via $\alpha$ carboxylate and the amide nitrogen of the glutamate moiety [22]. Many publications focus on the synthesis and characterization of metal-folate complexes. Still, they do not discuss their biological activity although such complexes might have high selectivity towards FR over expressing cells and thus a distinct biological activity and anticancer properties.

Here, we describe the synthesis of new metal-folate complexes as therapeutic agents. New metal-folate complexes were formed from the chemical reactions between $\mathrm{FAH}_{2}$ and some metal ions like Ga(III), Ge(IV), and Hf(IV). The synthesized folate complexes were discussed by using microanalytical, spectral tools, and thermogravimetric analysis. An antimicrobial assessment for the synthesized folate complexes towards bacteria and fungi species and the anticancer properties have been studied, for instance, on the germanium(IV)-folate complex against the human hepatocellular carcinoma (HepG-2) cell line.

\section{Materials and Methods}

2.1. Chemicals and Equipment. The pure grade chemical materials $\left(\mathrm{GaCl}_{3}, \mathrm{GeCl}_{4}, \mathrm{HfCl}_{4}\right.$, and folic acid) were received from Sigma-Aldrich chemical company. The microanalytical, physical, and spectral measurements with corresponding models are listed as follows:

2.2. Preparation of Folate Complexes. The folate complexes with the molecular formulas $\mathrm{NH}_{4}\left[\mathrm{Ga}(\mathrm{FA})_{2}\right] \cdot 4 \mathrm{H}_{2} \mathrm{O}$ (1), $\left[\mathrm{Ge}(\mathrm{FA})_{2}\right] \cdot 3 \mathrm{H}_{2} \mathrm{O}$ (2), and $\left[\mathrm{Hf}(\mathrm{FA})_{2}\right] \cdot 3 \mathrm{H}_{2} \mathrm{O}$ (3) were

\begin{tabular}{lc}
\hline Analysis technique & Instruments \\
\hline Elemental analysis & PerkinElmer, CHN 2400 \\
Conductance & Jenway 4010 conductivity meter \\
FTIR spectra & Bruker FTIR spectrophotometer \\
Electronic spectra & UV2 Unicam UV/Vis spectrophotometer \\
Magnetic & Magnetic susceptibility balance \\
susceptibility & Varian mercury VX-300 NMR \\
${ }^{1}$ HNMR spectra & spectrometer, 300 MHz \\
& TG/DTG-50H, Shimadzu \\
Thermogravimetric & thermogravimetric analyzer \\
SEM & Quanta FEG 250 equipment \\
XRD & X'Pert PRO PAN analytical, with copper \\
TEM & target
\end{tabular}

synthesized using the following procedure. Mixtures of $2.0 \mathrm{mmol}$ of $\mathrm{GaCl}_{3}, \mathrm{GeCl}_{4}$, or $\mathrm{HfCl}_{4}$ with $4.0 \mathrm{mmol}$ of $\mathrm{FAH}_{2}$ were stirred in $25 \mathrm{~mL}$ of $\mathrm{CH}_{3} \mathrm{OH}$ solvent. The $\mathrm{pH}$ of the mixtures was adjusted to about $7.7-8.0$ by adding ammonia solution $(0.2 \mathrm{M})$ dropwise and refluxed at about $\sim 60^{\circ} \mathrm{C}$ for $3 \mathrm{~h}$. The solutions of these mixtures were reduced by leaving them still for 1 week. The solid yields of folate complexes reached $60-66 \%$, with a higher melting point above $300^{\circ} \mathrm{C}$. The microanalysis (\%) of the elements $(\mathrm{C}, \mathrm{H}$, and $\mathrm{N})$ for the three synthesized complexes is summarized as follows:

\begin{tabular}{lccc}
\hline Complexes & Elements & Calc. (\%) & Found (\%) \\
\hline \multirow{3}{*}{1} & $\mathrm{C}$ & 43.91 & 43.66 \\
& $\mathrm{H}$ & 4.27 & 4.20 \\
& $\mathrm{~N}$ & 18.22 & 18.77 \\
\hline \multirow{3}{*}{2} & $\mathrm{C}$ & 45.35 & 45.31 \\
& $\mathrm{H}$ & 4.26 & 4.21 \\
& $\mathrm{~N}$ & 19.02 & 19.33 \\
3 & $\mathrm{C}$ & 41.03 & 41.11 \\
& $\mathrm{H}$ & 4.36 & 4.31 \\
& $\mathrm{~N}$ & 17.75 & 17.31 \\
\hline
\end{tabular}

2.3. Antimicrobial Inhibitions. A modified Kirby-Bauer experiment was used to assess antimicrobial inhibitions [23]. A cytotoxicity assay for the germanium(IV)-folate complex was performed using the human hepatocellular carcinoma 
(HepG-2) cell line $[24,25]$. The HepG-2 cell line was obtained from the VACSERA Tissue Culture Unit.

\section{Results and Discussion}

3.1. Molar Conductance. The molar ratios and conductance behaviors of gallium(III), germanium(IV), and hafnium(IV) folate complexes have been discussed. The elemental analyses are consistent with 1:2 (metal: ligand) stoichiometry. The synthesized complexes are insoluble in polar solvents but soluble in common organic solvents like DMF and DMSO. Gallium(III), germanium(IV), and hafnium(IV) folate complex solutions dissolved in DMSO showed slightly low conductance $\left(\Lambda_{\mathrm{m}}=14-30 \mathrm{ohm}^{-1} \mathrm{~cm}^{2} \mathrm{~mol}^{-1}\right)$, suggesting a nonelectrolyte behavior [26].

3.2. Infrared Interpretations. The FTIR spectra for the $\mathrm{FAH}_{2}$ free chelate and the synthesized metal complexes are shown in Figures 2(a) and 2(b). All complexes have similar spectra, which reflect similar structural characteristics for these complexes. The significant infrared spectral bands were assigned and inserted in Table 1 . These assignments can be summarized with the following evidences:

(i) The folic acid-free ligand has a stretching vibration band at $1702 \mathrm{~cm}^{-1}$, which is attributed to $v$ $(\mathrm{C}=\mathrm{O})_{\text {ketonic }}$ of the carboxylic group; this band is overlapped with the $v(\mathrm{C}=\mathrm{O})$ amide group [16]. This band was shifted to lower wavenumber in all complexes, with a marked decrease in the spectral intensity. Interestingly, the bands present at 1604 and $1485 \mathrm{~cm}^{-1}$ were assigned to $v_{\text {as }}\left(\mathrm{COO}^{-}\right)$and $v_{\mathrm{s}}$ $\left(\mathrm{COO}^{-}\right)$stretching vibrations in the case of the spectrum of the folic acid ligand. These bands were shifted to higher and lower frequencies, respectively, under complexation because of the involvement of the oxygen of the carboxylate group in the coordination towards metal ions. The difference between antisymmetric ( $\left.\nu_{\text {as }} \mathrm{COO}\right)$ and symmetric $\left(v_{\mathrm{s}} \mathrm{COO}\right)$ stretching vibrations for the COO group gives an impression about the speculated molecular structure of the folate complexes [27]. The coordination mode of the carboxylate group was discussed by Deacon and Phillips [28] according to the $\Delta v=\left[v_{\mathrm{as}}(\mathrm{COO})-v_{\mathrm{s}}(\mathrm{COO})\right]$ relationship. The interactions between the metal ions and the carboxylate group were (a) monodentate fashion when $\Delta v$ $>200 \mathrm{~cm}^{-1}$, (b) bidentate/chelating fashion when $\Delta v$ is smaller than ionic form, and (c) bridging bidentate when $\Delta v$ has nearly ionic values. The observed $\Delta v$ values for all the complexes exhibited within the $211-217 \mathrm{~cm}^{-1}$ range, as discussed in Table 2. Therefore, the carboxylate groups chelated to metal ions as a unidentate mode [28].

(ii) The $\mathrm{FAH}_{2}$-free ligand has a distinguished band at $3318 \mathrm{~cm}^{-1}$ that is attributed to the $\nu(\mathrm{N}-\mathrm{H})$ of the amido group. This band blue-shifted in the case of the spectra of the synthesized complexes, and the characteristic band for $\delta(\mathrm{NH})$ amide is downshifted in the complexes relative to the free ligand. This result is in agreement with the HNMR data, which confirmed the participation of the amide nitrogen in the coordination of metal ions. So, this situation confirms the presence of a folate ligand as a tridentate ONO chelate through $\alpha$-COO, $\beta$-COO, and amide groups $[2,21]$.

(iii) There are two vibration bands in the case of the spectrum of $\mathrm{FAH}_{2}$-free ligand located at 3558 and $3411 \mathrm{~cm}^{-1}$, which are assigned to the $\nu(\mathrm{O}-\mathrm{H})$ vibrations of the carboxylic groups. These bands are present with broadening in the spectra of folate complexes due to the presence of the crystalline water molecules [1, 29, 30].

(iv) The weak and very weak intensity bands in the range of $600-400 \mathrm{~cm}^{-1}$ are attributed to stretching vibrations of $\mathrm{M}-\mathrm{N}$ and $\mathrm{M}-\mathrm{O}$ [31]. These data assume a tridentate manner of coordination for the folate chelate towards metal ions by deprotonating the two carboxylic groups of glutamic acid and $\mathrm{NH}$ of the amide group.

3.3. Electronic Spectra. The UV-visible spectrum of folic acid (Figure 3) exhibits absorbance bands at 220 and (290 and $380 \mathrm{~nm}$ ) attributed to $\pi \longrightarrow \pi^{*}$ and $n \longrightarrow \pi^{*}$ transitions. The first peak is probably due to the alkyl and aromatic species, while the other bands are assigned to $\mathrm{COOH}, \mathrm{NH}, \mathrm{NH}_{2}$, and $\mathrm{C}=\mathrm{O}$ groups [32]. These bands are shifted to longer wavelengths, which support the complexity of metal ions with carboxylic and amide groups (Figure 3). The folate complexes have bands within the $428-454 \mathrm{~nm}$ range due to the $\mathrm{L} \longrightarrow \mathrm{M}_{\mathrm{CT}}$ transitions $[33,34]$.

3.4. ${ }^{1} \mathrm{HNMR}$ Study. The ${ }^{1} \mathrm{HNMR}$ spectrum of the $\mathrm{FAH}_{2}$-free ligand in DMSO- $\mathrm{d}_{6}$ (Figure $1 \mathrm{~S}$ and Table 3 ) has a quadrature signal obtained at $\delta 2.317$ and $2.293 \mathrm{ppm}$ of the protons $\mathrm{H}$ (21) and triplet signal at $\delta 2.504,2.501$, and $2.495 \mathrm{ppm}$ of the protons $\mathrm{H}$ (22) due to the methylene $\mathrm{CH}_{2}$ group. The signals were shifted downfield in the case of the synthesized folate complexes (Figures $2 \mathrm{~S}$ and $3 \mathrm{~S}$ and Table 3 ). A signal at $\delta$ $8.093 \mathrm{ppm}$ of the proton $\mathrm{H}(18)$ is due to the $\mathrm{NH}$ amide group. After complexation, this signal was upfield shifted with a chemical shift difference at $0.305-0.338 \mathrm{ppm}$, thus supporting the amido group's involvement in the chelation process [35]. The triplet signal at $\delta 4.476 \mathrm{ppm}$ of the proton $\mathrm{H}$ (19) is due to the methylene group. This group significantly affected the spectra of the folate complexes, which was shifted to the low field. This was because of the effect of attaching the amide and carboxylic groups. A signal at $\delta$ $4.496 \mathrm{ppm}$ of the proton $\mathrm{H}$ (9) is due to shifting of the methylene $\mathrm{CH}_{2}$ group to a low field, a result of the cycling effect from one side and the $\mathrm{NH}$ group effect from the other side. A single signal at $\delta 8.5 \mathrm{ppm}$ of the proton $\mathrm{H}(7)$ is due to the $(\mathrm{CH}=\mathrm{N})$ 2-pyrazine group. These findings strongly 


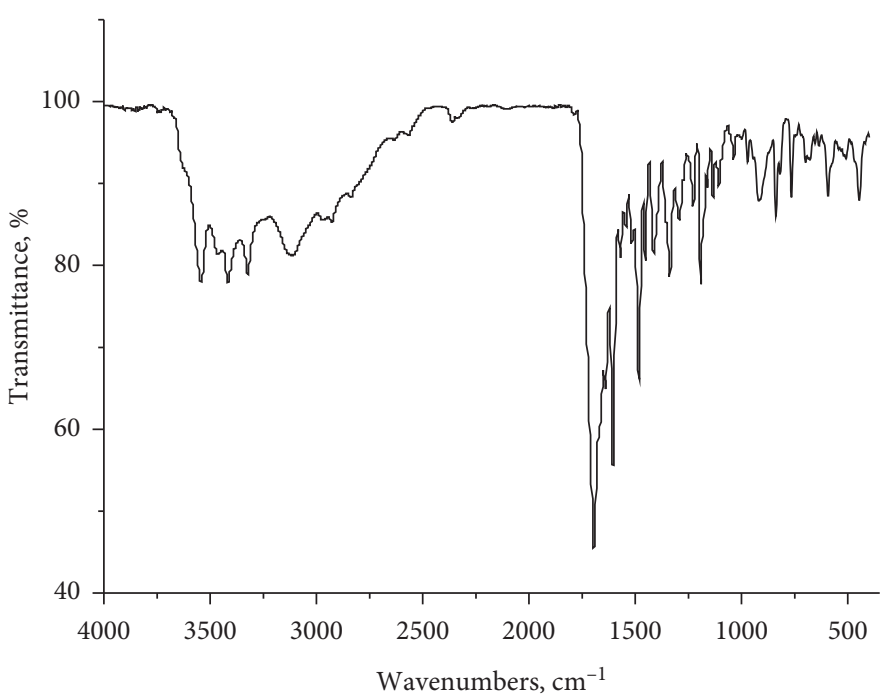

(a)
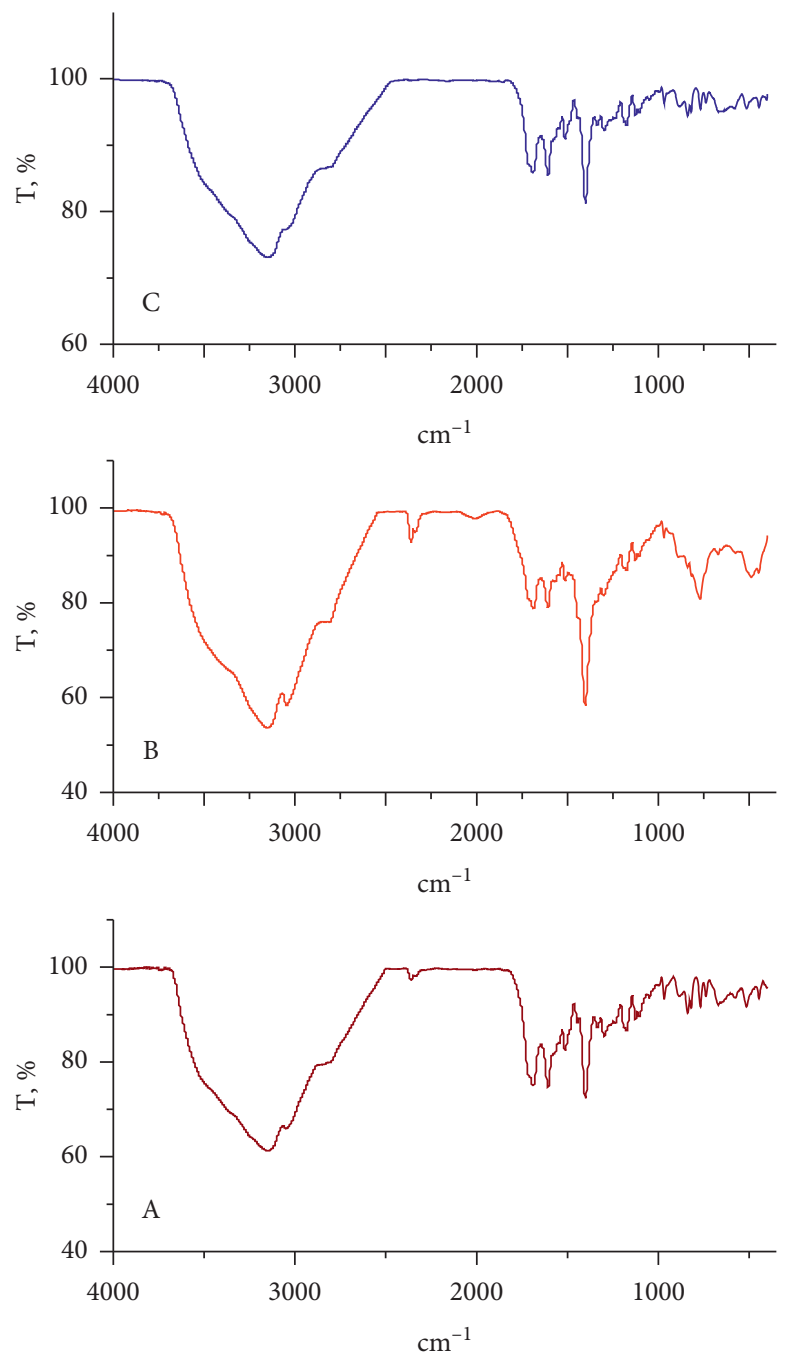

(b)

Figure 2: (a) Infrared spectrum of a pure folic acid drug; (b) infrared spectra of A : Ga(III), B : Ge(IV), and C: Hf(IV) folate complexes. 
TABLE 1: Infrared spectral frequency data of $\mathrm{FAH}_{2}$ and synthesized complexes.

\begin{tabular}{|c|c|c|c|c|}
\hline Assignments & $\mathrm{FAH}_{2}$ & $\mathrm{Ga}(\mathrm{III})$ complex & Ge(IV) complex & Hf(IV) complex \\
\hline$v(\mathrm{OH}) ; \mathrm{H}_{2} \mathrm{O}$ & $\begin{array}{l}3558 \\
3411\end{array}$ & 3487 & 3486 & 3468 \\
\hline$\nu(\mathrm{NH})$ amide & 3318 & 3153 & 3158 & 3139 \\
\hline$v_{\mathrm{as}}(\mathrm{CH})$ & $\begin{array}{l}3119 \\
2933\end{array}$ & 3043 & 3022 & 3003 \\
\hline$v_{\mathrm{s}}(\mathrm{CH})$ & 2826 & 2810 & 2791 & 2790 \\
\hline $\mathrm{N}(\mathrm{COOH})$ & 1702 & 1697 & 1697 & 1697 \\
\hline$v_{\text {as }}(\mathrm{COO}-)$ & 1604 & 1618 & 1618 & 1618 \\
\hline$\delta(\mathrm{NH})$ amide II & 1564 & 1525 & 1523 & 1525 \\
\hline$v_{\mathrm{s}}(\mathrm{COO}-)$ & 1485 & 1405 & 1401 & 1399 \\
\hline$v_{\text {as }}(\mathrm{CC})$ & 1338 & 1286 & 1298 & 1259 \\
\hline$v(\mathrm{CN})$ & 1192 & 1178 & 1178 & 1178 \\
\hline$v_{\mathrm{s}}(\mathrm{CC})$ & 913 & 970 & 900 & 966 \\
\hline$\delta(\mathrm{CC})$ & 833 & 846 & 767 & 873 \\
\hline$v(\mathrm{M}-\mathrm{O})$ & - & 510 & 501 & 514 \\
\hline
\end{tabular}

TABLE 2: Stretching vibration bands of the carboxylate group for the $\mathrm{FAH}_{2}$ and synthesized complexes.

\begin{tabular}{lcccc}
\hline Compound & $\nu_{\text {as }}(\mathrm{COO})$ & $\nu_{\mathrm{s}}(\mathrm{COO})$ & $\Delta=v_{\text {as }}(\mathrm{COO})-v_{\mathrm{s}}(\mathrm{COO})$ & 119 \\
\hline $\mathrm{FAH}_{2}$ & 1604 & 1485 & 213 & Bonding mode \\
$\mathrm{Ga}(\mathrm{III})$ complex & 1618 & 1405 & 217 & Monodentate \\
$\mathrm{Ge}(\mathrm{IV})$ complex & 1618 & 1401 & 211 & Monodentate \\
$\mathrm{Hf}(\mathrm{IV})$ complex & 1610 & 1399 & Monodentate \\
\hline
\end{tabular}

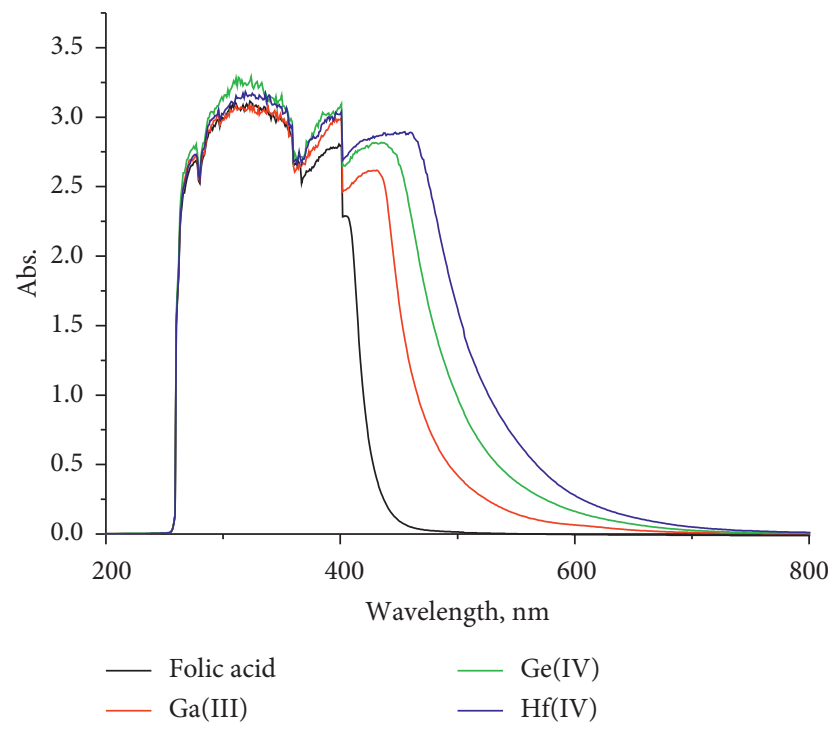

FIgURE 3: Electronic spectra of folic acid-free chelate and its Ga(III), Ge(IV), and $\mathrm{Hf}(\mathrm{IV})$ complexes.

TABLE 3: The ${ }^{1}$ HNMR spectral data of the $\mathrm{FAH}_{2}$ and synthesized complexes.

\begin{tabular}{lccr}
\hline Number of protons & & $\delta$ (ppm) & \\
& $\mathrm{FAH}_{2}$ & Ga(III) complex & Ge(III) complex \\
\hline $\mathrm{H}_{7}$ & 8.648 & $8.621,8.617$ & 7.627 \\
$\mathrm{H}_{18}$ & 8.093 & $7.788,7.766$ & $7.778,7.755$ \\
$\mathrm{H}_{13,15}$ & 7.664 & 7.597 & 7.592 \\
$\mathrm{H}_{10}$ & 7.635 & 7.571 & 7.563 \\
$\mathrm{H}_{12,16}$ & $6.630,6.659$ & $6.647,6.621$ & $6.648,6.557$ \\
$\mathrm{H}_{9}$ & 4.496 & $4.464,4.449$ & $4.467,4.447$ \\
$\mathrm{H}_{19}$ & 4.476 & $4.164,4.144$ & $4.154,4.131$ \\
$\mathrm{H}_{22}$ & $2.504,2.501,2.495$ & $2.507,2.501,2.495$ & $2.513,2.507,2.501$ \\
$\mathrm{H}_{21 \mathrm{a}}$ & 2.317 & $2.224,2.202$ & $2.223,2.1987$ \\
$\mathrm{H}_{21 \mathrm{~b}}$ & 2.293 & $1.971,1.950,1.903$ & $1.937,1.916,1.892$ \\
\hline
\end{tabular}




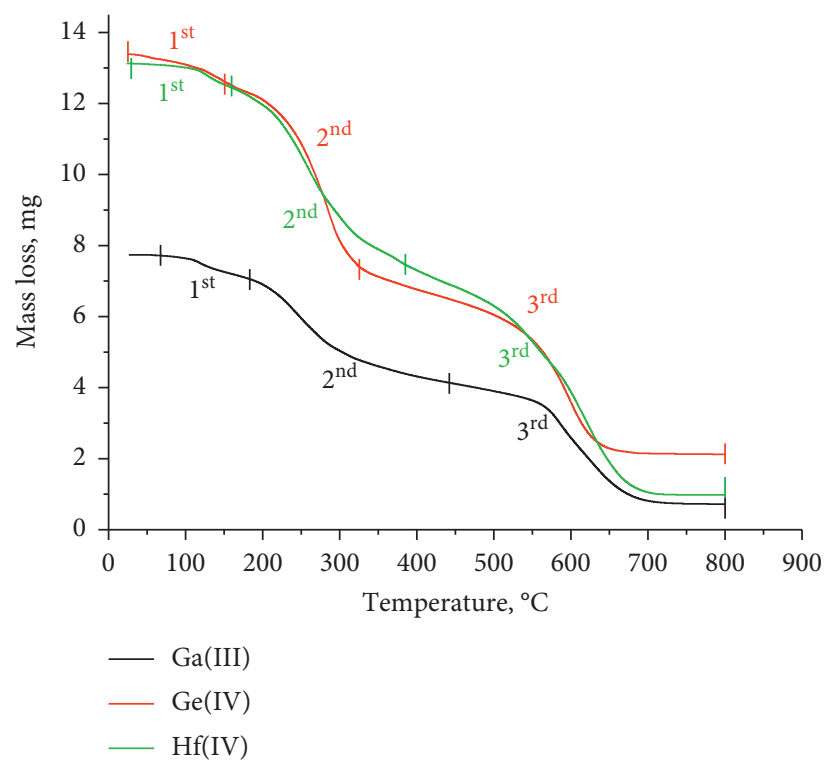

Figure 4: TGA curves of Ga(III), Ge(IV), and Hf(IV) folate complexes.

TABLE 4: TGA decomposition data of the $\mathrm{FAH}_{2}$ ligand and synthesized complexes.

\begin{tabular}{|c|c|c|c|c|c|}
\hline Compounds & Steps & Temp. range $\left({ }^{\circ} \mathrm{C}\right)$ & Decomposed assignments & Residual species & Mass loss (\%) \\
\hline $\mathrm{Ga}(\mathrm{III})$ & $\begin{array}{l}1^{\text {st }} \\
2^{\text {nd }} \\
3^{\text {rd }}\end{array}$ & $\begin{array}{c}56-181 \\
181-445 \\
445-800 \\
\end{array}$ & $\begin{array}{c}-4 \mathrm{H}_{2} \mathrm{O}+\mathrm{NH}_{3} \\
-7 \mathrm{C}_{2} \mathrm{H}_{2}+2 \mathrm{NO}+5 \mathrm{~N}_{2} \\
-10 \mathrm{C}_{2} \mathrm{H}_{2}+2 \mathrm{CO}+4 \mathrm{O}_{2}+\mathrm{N}_{2}\end{array}$ & $\mathrm{Ga}+$ carbon & 90.698 \\
\hline $\mathrm{Ge}(\mathrm{IV})$ & $\begin{array}{l}1^{\text {st }} \\
2^{\text {nd }} \\
3^{\text {rd }}\end{array}$ & $\begin{array}{c}30-146 \\
146-321 \\
321-800 \\
\end{array}$ & $\begin{array}{c}-3 \mathrm{H}_{2} \mathrm{O} \\
-7 \mathrm{C}_{2} \mathrm{H}_{2}+2 \mathrm{NO}+5 \mathrm{~N}_{2} \\
-10 \mathrm{C}_{2} \mathrm{H}_{2}+2 \mathrm{CO}+4 \mathrm{O}_{2}+\mathrm{N}_{2}\end{array}$ & $\mathrm{Ge}+$ carbon & 84.167 \\
\hline $\mathrm{Hf}(\mathrm{IV})$ & $\begin{array}{l}1^{\text {st }} \\
2^{\text {nd }} \\
3^{\text {rd }}\end{array}$ & $\begin{array}{c}34-154 \\
154-380 \\
380-800\end{array}$ & $\begin{array}{c}-3 \mathrm{H}_{2} \mathrm{O} \\
-7 \mathrm{C}_{2} \mathrm{H}_{2}+2 \mathrm{NO}+5 \mathrm{~N}_{2} \\
-10 \mathrm{C}_{2} \mathrm{H}_{2}+2 \mathrm{CO}+4 \mathrm{O}_{2}+\mathrm{N}_{2}\end{array}$ & $\mathrm{Hf}+$ carbon & 84.023 \\
\hline
\end{tabular}

support the coordination site through the tridentate fashion of the folate ligand $[21,35]$.

3.5. Thermogravimetric Analysis. The stabilities of the thermal decompositions of the synthesized metal chelates were discussed based on the TGA analysis (Figure 4 and Table 4). The thermal decomposition of the $\mathrm{NH}_{4}\left[\mathrm{Ga}(\mathrm{FA})_{2}\right] \cdot 4 \mathrm{H}_{2} \mathrm{O}$ complex (I) takes place through three degradation stages with a mass loss of $8.66 \%$ (temperature range between 56 and $181^{\circ} \mathrm{C}$ ), $37.98 \%$ (temperature range between 181 and $445^{\circ} \mathrm{C}$ ), and $44.056 \%$ (temperature range between 445 and $800^{\circ} \mathrm{C}$ ), respectively. The remaining residual mass is due to the gallium metal contaminated with few unoxidized carbon atoms. The thermal decomposition of the $\left[\mathrm{Ge}(\mathrm{FA})_{2}\right] \cdot 3 \mathrm{H}_{2} \mathrm{O}$ complex(II) passes through three steps. The first decomposition step is within the $30-146^{\circ} \mathrm{C}$ temperature range and has a mass loss of $5.45 \%$. The second step is within the $146-321^{\circ} \mathrm{C}$ range and has a mass loss of $38.54 \%$. The third step is within the $321-800^{\circ} \mathrm{C}$ range, with a mass loss of $39.58 \%$. The germanium metal polluted with few unoxidized carbon atoms is a final residue at $800^{\circ} \mathrm{C}$. The $\left[\mathrm{Hf}(\mathrm{FA})_{2}\right] \cdot 3 \mathrm{H}_{2} \mathrm{O}$ complex(III) was decomposed through three steps within temperature ranges at $34-154^{\circ} \mathrm{C}, 154-380^{\circ} \mathrm{C}$, and $358-800^{\circ} \mathrm{C}$ with mass losses of $4.86 \%, 33.55 \%$, and $45.60 \%$, respectively. At $800^{\circ} \mathrm{C}$, the hafnium metal was mixed with some nonoxidized carbon atoms, which represents the residual material.

3.6. Kinetic and Thermodynamic Parameters. Using official integral methods, including Horowitz-Metzger (HM) [36] and Coats-Redfern (CR) methods [37], the parameters of the kinetic thermodynamic process are calculated and listed in Table 5. From the theoretical data, it can be deduced that the activation energies and, by extension, the thermal stability of the folate complexes are ordered as $\mathrm{Ga}(\mathrm{III})>\mathrm{Ge}(\mathrm{IV})>\mathrm{Hf}(\mathrm{IV})$. The results of the two methods used to calculate the thermodynamic parameters are satisfactorily consistent with each other. The pyrolysis steps of the folate complexes are nonspontaneous $\left(\Delta S^{*}\right)$ with negative data due to the thermal stability of the synthesized complexes.

3.7. Speculated Structure of Folate Complexes. The proposed structures of $\mathrm{NH}_{4}\left[\mathrm{Ga}(\mathrm{FA})_{2}\right] \cdot 4 \mathrm{H}_{2} \mathrm{O}(\mathbf{1}),\left[\mathrm{Ge}(\mathrm{FA})_{2}\right] \cdot 3 \mathrm{H}_{2} \mathrm{O}(2)$, and $\left[\mathrm{Hf}(\mathrm{FA})_{2}\right] \cdot 3 \mathrm{H}_{2} \mathrm{O}(3)$ folate complexes (Figure 5) were 
TABLE 5: Kinetic thermodynamic parameters of the $\mathrm{FAH}_{2}$ and synthesized complexes.

\begin{tabular}{|c|c|c|c|c|c|c|}
\hline \multirow{2}{*}{ Compound } & \multirow{2}{*}{ Steps } & \multicolumn{5}{|c|}{ Coats-Redfern equation } \\
\hline & & $r$ & $E\left(\mathrm{~kJ} \mathrm{~mol}^{-1}\right)$ & $\Delta S^{*}\left(\mathrm{Jk}^{-1} \mathrm{~mol}^{-1}\right)$ & $\Delta H^{*}\left(\mathrm{~kJ} \mathrm{~mol}{ }^{-1}\right)$ & $\Delta G^{*}\left(\mathrm{~kJ} \mathrm{~mol}{ }^{-1}\right)$ \\
\hline \multirow{3}{*}{ Ga(III) complex } & $1^{\text {st }}$ & 0.9976 & $4.95^{*} 10^{4}$ & $-1.68 * 10^{2}$ & $4.63 * 10^{4}$ & $1.12 * 10^{5}$ \\
\hline & $2^{\text {nd }}$ & 0.9429 & $2.82 * 10^{4}$ & $-1.38 * 10^{2}$ & $2.34^{*} 10^{4}$ & $1.04 * 10^{5}$ \\
\hline & $3^{\text {rd }}$ & 0.9872 & $1.10^{*} 10^{5}$ & $-1.79 * 10^{2}$ & $1.02 * 10^{5}$ & $2.62 * 10^{5}$ \\
\hline \multirow{3}{*}{$\mathrm{Ge}(\mathrm{IV})$ complex } & $1^{\text {st }}$ & 0.9896 & $2.91^{*} 10^{4}$ & $-1.71 * 10^{2}$ & $2.61 * 10^{4}$ & $8.80^{*} 10^{4}$ \\
\hline & $2^{\text {nd }}$ & 0.9808 & $5.02 * 10^{4}$ & $-1.75 * 10^{2}$ & $4.60 * 10^{4}$ & $1.34 * 10^{5}$ \\
\hline & $3^{\text {rd }}$ & 0.9477 & $5.21 * 10^{4}$ & $-1.43 * 10^{2}$ & $4.52 * 10^{4}$ & $1.64^{*} 10^{5}$ \\
\hline \multirow{3}{*}{ Hf(IV) complex } & $1^{\text {st }}$ & 0.9987 & $3.18^{*} 10^{4}$ & $-1.65 * 10^{2}$ & $2.87^{*} 10^{4}$ & $8.94^{*} 10^{4}$ \\
\hline & $2^{\text {nd }}$ & 0.9892 & $4.30^{*} 10^{4}$ & $-1.62 * 10^{2}$ & $3.85^{*} 10^{4}$ & $1.26^{*} 10^{5}$ \\
\hline & $3^{\text {rd }}$ & 0.9970 & $4.90^{*} 10^{4}$ & $-1.60 * 10^{2}$ & $4.45^{*} 10^{4}$ & $1.32 * 10^{5}$ \\
\hline \multirow{2}{*}{ Compound } & & \multicolumn{5}{|c|}{ Horowitz and Metzger equation } \\
\hline & Steps & $r$ & $E\left(\mathrm{~kJ} \mathrm{~mol}{ }^{-1}\right)$ & $\Delta S^{*}\left(\mathrm{Jk}^{-1} \mathrm{~mol}^{-1}\right)$ & $\Delta H^{*}\left(\mathrm{~kJ} \mathrm{~mol}{ }^{-1}\right)$ & $\Delta G^{*}\left(\mathrm{~kJ} \mathrm{~mol}{ }^{-1}\right)$ \\
\hline \multirow{3}{*}{$\mathrm{Ga}(\mathrm{III})$ complex } & $1^{\text {st }}$ & 0.9895 & $5.60 * 10^{4}$ & $-1.42 * 10^{2}$ & $5.27^{*} 10^{4}$ & $1.08 * 10^{5}$ \\
\hline & $2^{\text {nd }}$ & 0.9372 & $3.62 * 10^{4}$ & $-2.37^{*} 10^{2}$ & $3.13^{*} 10^{4}$ & $1.70 * 10^{5}$ \\
\hline & $3^{\text {rd }}$ & 0.9858 & $1.27 * 10^{5}$ & $-1.56 * 10^{2}$ & $1.20 * 10^{5}$ & $2.60 * 10^{5}$ \\
\hline \multirow{3}{*}{$\mathrm{Ge}(\mathrm{IV})$ complex } & $1^{\text {st }}$ & 0.9846 & $3.50 * 10^{4}$ & $-1.90 * 10^{2}$ & $3.20 * 10^{4}$ & $1.01 * 10^{5}$ \\
\hline & $2^{\text {nd }}$ & 0.9969 & $5.94 * 10^{4}$ & $-1.73 * 10^{2}$ & $5.51^{*} 10^{4}$ & $1.43 * 10^{5}$ \\
\hline & $3^{\text {rd }}$ & 0.9706 & $6.78^{*} 10^{4}$ & $-2.21 * 10^{2}$ & $6.09^{*} 10^{4}$ & $2.45^{*} 10^{5}$ \\
\hline \multirow{3}{*}{ Hf(IV) complex } & $1^{\text {st }}$ & 0.9778 & $3.95^{*} 10^{4}$ & $-1.78 * 10^{2}$ & $3.64 * 10^{4}$ & $1.02 * 10^{5}$ \\
\hline & $2^{\text {nd }}$ & 0.9827 & $5.20^{*} 10^{4}$ & $-1.97 * 10^{2}$ & $4.75^{*} 10^{4}$ & $1.54^{*} 10^{5}$ \\
\hline & $3^{\text {rd }}$ & 0.9822 & $6.80^{*} 10^{4}$ & $-1.92 * 10^{2}$ & $5.80^{*} 10^{4}$ & $2.34 * 10^{5}$ \\
\hline
\end{tabular}

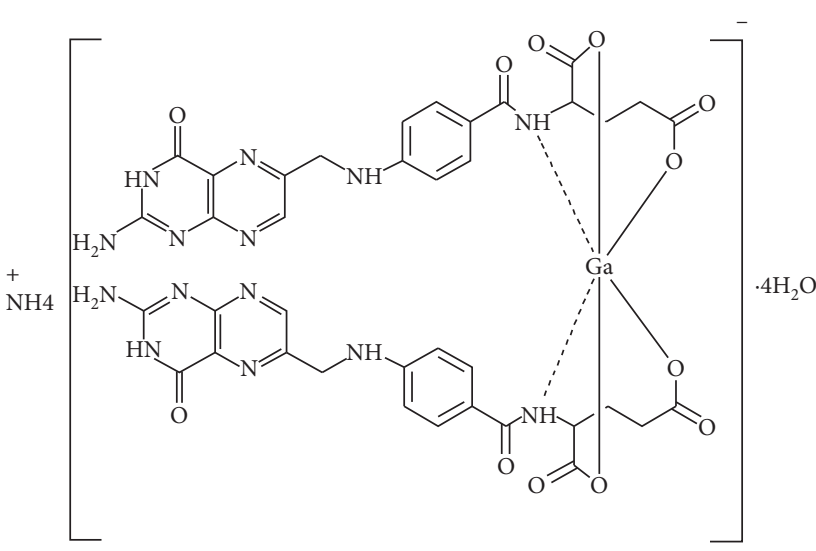

(a)

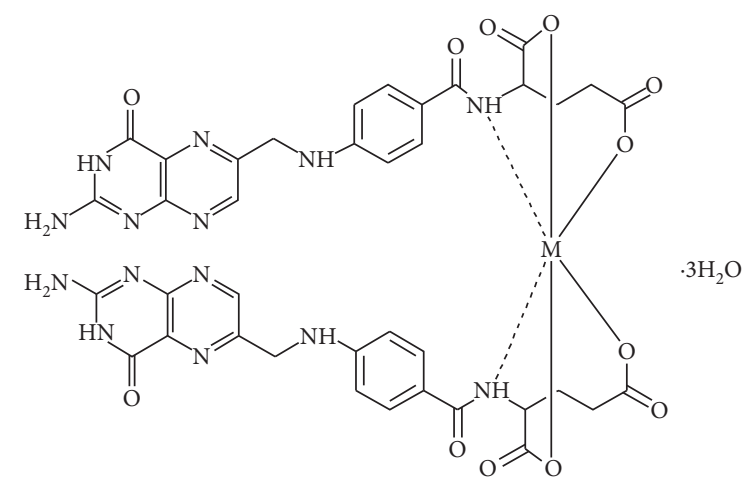

(b)

Figure 5: (a) Speculated structure of the Ga(III) folate complex; (b) speculated structures of Ge(IV) and Hf(IV) folate complexes.

discussed based on the elemental analysis, conductance, FTIR, UV-Vis, ${ }^{1} \mathrm{HNMR}$, and TGA measurements. The various analyses performed in this study deduced that the coordination between the folic acid ligand and central metal ions passes through oxygen atoms of the carboxylate group and nitrogen atoms of amide groups.

3.8. XRD, SEM, and TEM Analyses. In X-ray diffractograms of the folate complexes, major patterns were scanned within the $4^{\circ}$ to $80^{\circ} 2 \theta$ range. The XRD patterns of the folate complexes (Figure 6) are completely different from those of folic acid [38] due to the formation of new coordination compounds. The X-ray diffractogram of the three synthesized metal-folate complexes is semicrystalline as well as amorphous in nature. According to the Scherrer equation, the crystallite sizes of the synthesized folate complexes were calculated using full width at half maximum of the diffraction peak. The crystallite sizes of the folate complexes were located at $\sim 30-100 \mathrm{~nm}$. The SEM images of the synthesized complexes are given in Figure 7. The surface morphology changes with changes in the ionic radius of specific metal ions; both the images have many irregular shapes. TEM micrographs of the $\mathrm{Ga}^{3+}, \mathrm{Ge}^{4+}$, and $\mathrm{Hf}^{4+}$ complexes (Figure 8) demonstrated particles within a nanosize range. The average particle diameter for folate complexes was in the range of $30-100 \mathrm{~nm}$, in agreement with the XRD data.

3.9. Biological Results. We report the results of in vitro microbial tests of the $\mathrm{FAH}_{2}$ drug and its gallium(III), germanium(IV), and hafnium(IV) complexes against a panel of bacteria and fungi species (Table 6 and Figure 9): 


\begin{tabular}{lcc}
\hline E. coli & B. subtilis & Aspergillus flavus \\
P. aeruginosa & S. aureus & Candida albicans \\
\hline
\end{tabular}

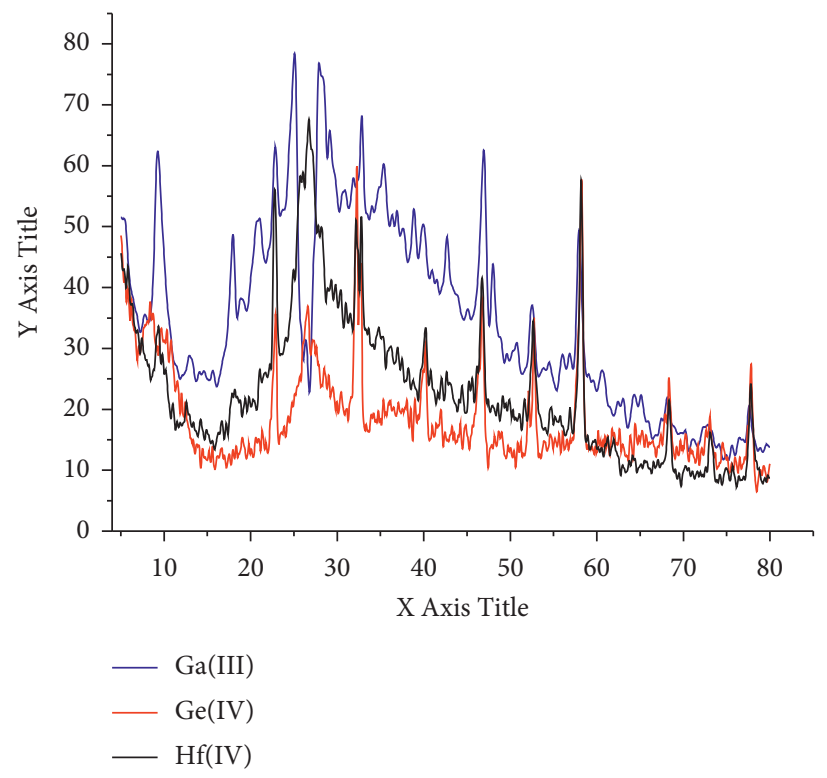

Figure 6: XRD patterns of $\mathrm{Ga}(\mathrm{III}), \mathrm{Ge}(\mathrm{IV})$, and $\mathrm{Hf}(\mathrm{IV})$ folate complexes.
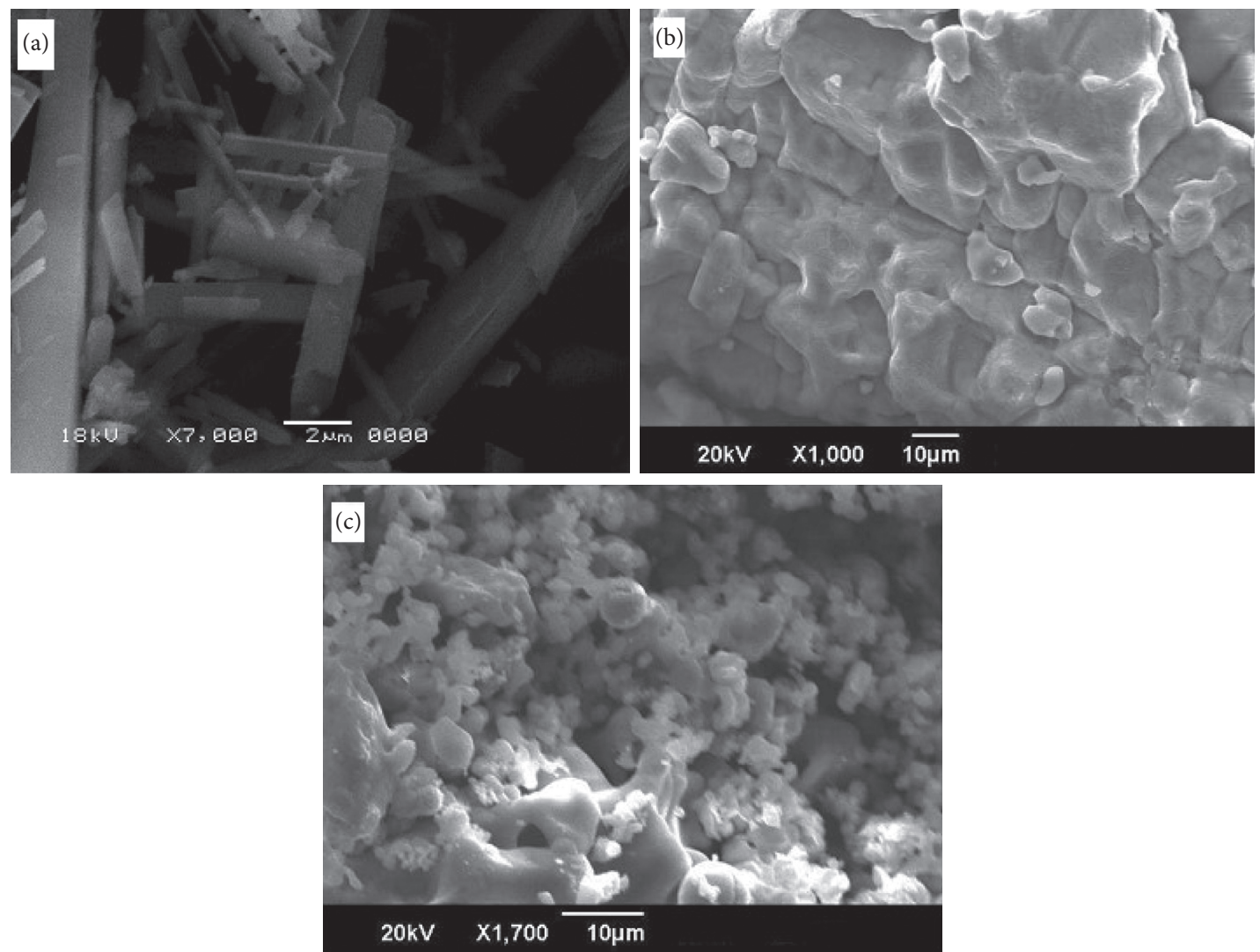

Figure 7: SEM images of (a) Ga(III), (b) Ge(IV), and (c) Hf(IV) folate complexes. 

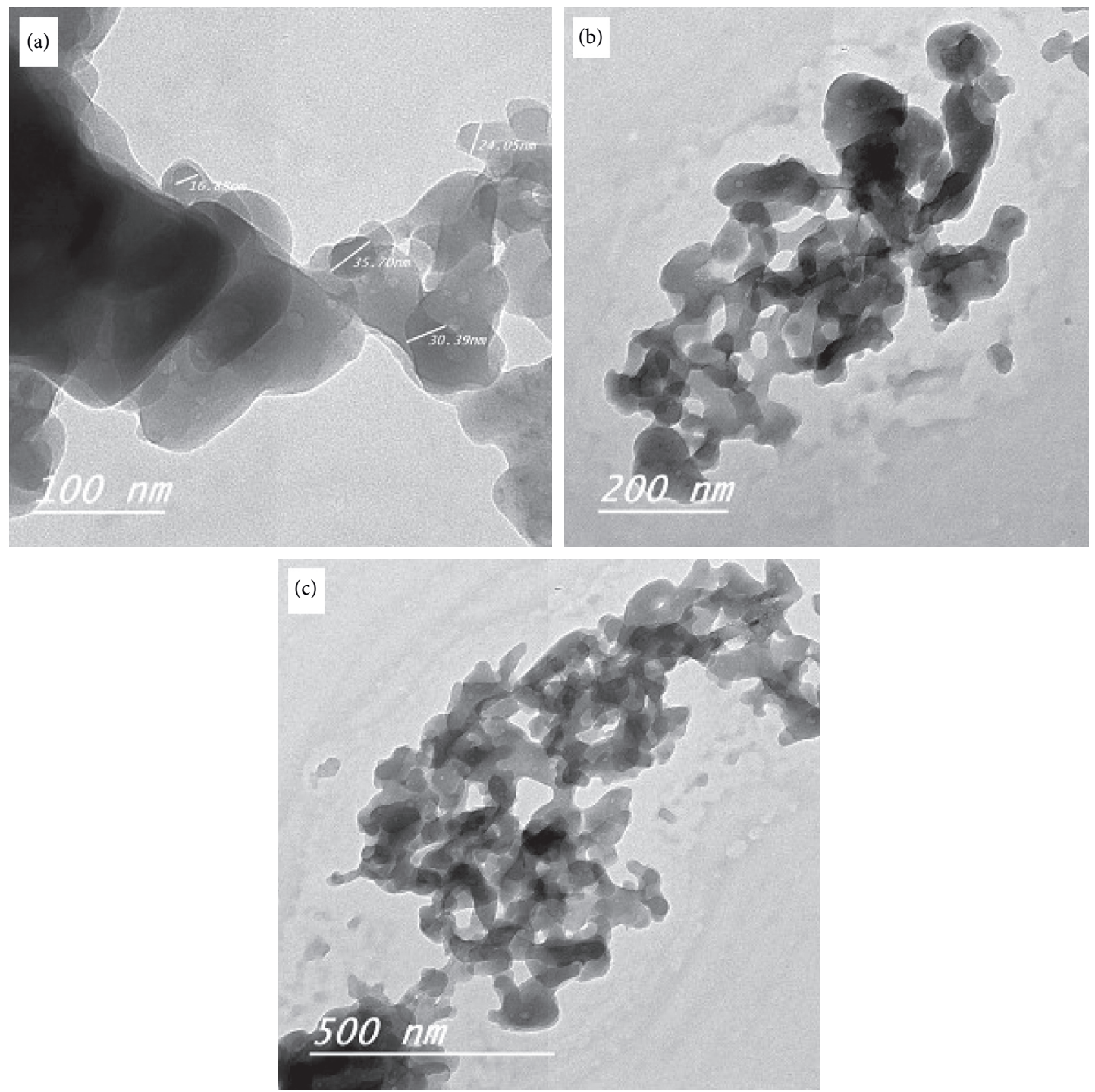

Figure 8: TEM pictures of (a) Ga(III), (b) Ge(IV), and (c) Hf(IV) folate complexes.

TABle 6: Antimicrobial assessments of $\mathrm{Ga}(\mathrm{III}), \mathrm{Ge}(\mathrm{IV})$, and $\mathrm{Hf}(\mathrm{IV})$ folate complexes.

\begin{tabular}{|c|c|c|c|c|c|c|}
\hline \multirow[b]{2}{*}{ Sample } & \multicolumn{6}{|c|}{ Inhibition zone diameter ( $\mathrm{mm} / \mathrm{mg}$ sample) } \\
\hline & $\begin{array}{c}\text { Bacillus } \\
\text { subtilis }\left(\mathrm{G}^{+}\right)\end{array}$ & $\begin{array}{l}\text { Escherichia } \\
\text { coli }\left(\mathrm{G}^{-}\right)\end{array}$ & $\begin{array}{l}\text { Pseudomonas } \\
\text { aeruginosa }\left(\mathrm{G}^{-}\right)\end{array}$ & $\begin{array}{l}\text { Staphylococcus } \\
\text { aureus }\left(\mathrm{G}^{+}\right)\end{array}$ & $\begin{array}{c}\text { Aspergillus } \\
\text { flavus (fungus) }\end{array}$ & $\begin{array}{l}\text { Candida } \\
\text { albicans } \\
\text { (fungus) }\end{array}$ \\
\hline Control: DMSO & 0.0 & 0.0 & 0.0 & 0.0 & 0.0 & 0.0 \\
\hline $\begin{array}{c}\text { Tetracycline } \\
\text { antibacterial agent }\end{array}$ & 34 & 32 & 34 & 30 & - & - \\
\hline $\begin{array}{l}\text { Amphotericin B } \\
\text { antifungal agent }\end{array}$ & - & - & - & - & 18 & 19 \\
\hline $\mathrm{FAH}_{2}$ & 16 & 19 & 17 & 13 & 2 & 5 \\
\hline $\mathrm{Ga}(\mathrm{III})$ complex & 29 & 12 & 13 & 23 & 7.0 & 16 \\
\hline Ge(IV) complex & 20 & 11 & 16 & 29 & 2.0 & 12 \\
\hline Hf(IV) complex & 30 & 19 & 10 & 14 & 11 & 20 \\
\hline
\end{tabular}

G: gram reaction. Solvent: DMSO.

Gallium(III), germanium(IV), and hafnium(IV) folate complexes were more active against B. subtilis and S. aureus bacteria than the free folic acid ligand drug. The
hafnium(IV) complex has a bactericidal efficiency against Escherichia coli. All folate metal complexes have antifungal activity against different kinds of fungi understudy rather 
TABLe 7: The inhibitory activities of the Ge(IV) complex against HepG cell line.

\begin{tabular}{lccccccccc}
\hline \multirow{2}{*}{ Conc. $(\mu \mathrm{g} / \mathrm{mL})$} & \multicolumn{9}{c}{ \%epG cell line } \\
& $\mathrm{Ab}$ & \% C & $\mathrm{Ab}$ & \% C & $\mathrm{Ab}$ & \% C & Abs av & Ave \% C \\
\hline 0 & 0.453 & 97.41935 & 0.476 & 102.3656 & 0.466 & 100.2151 & 0.465 & 100 & 1.431899 \\
0.1 & 0.429 & 92.25806 & 0.413 & 88.8172 & 0.401 & 86.0515 & 0.414333 & 89.10394 & 1.79521 \\
1 & 0.408 & 87.74194 & 0.400 & 86.02151 & 0.403 & 86.66667 & 0.403667 & 86.81004 & 0.501792 \\
10 & 0.411 & 88.3871 & 0.390 & 83.87097 & 0.404 & 86.88172 & 0.401667 & 86.37993 & 1.327617 \\
100 & 0.379 & 81.50538 & 0.384 & 82.58065 & 0.390 & 83.87097 & 0.384333 & 82.65233 & 0.683827 \\
1000 & 0.254 & 54.62366 & 0.256 & 55.05376 & 0.25 & 53.76344 & 0.253333 & 54.48029 & 0.379319 \\
\hline
\end{tabular}

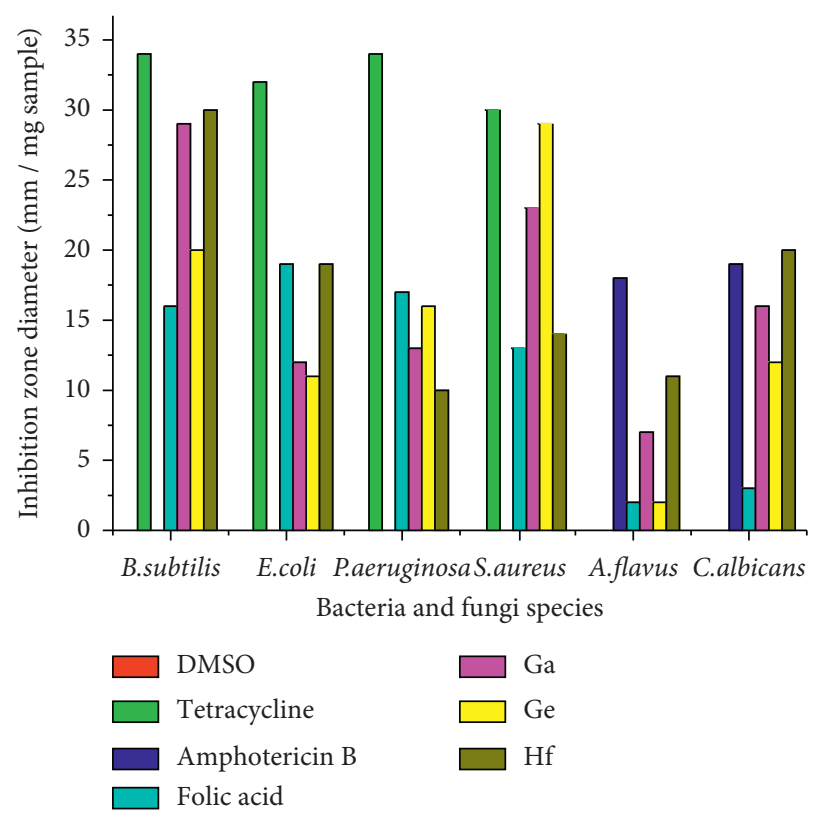

FIGURE 9: Inhibition zone diameter of DMSO control, "tetracycline” antibacterial agent, "amphotericin B" antifungal agent, and folic acid and its synthesized complexes against some bacteria and fungi species.

than free $\mathrm{FAH}_{2}$-free drugs. The folic acid ligand and its metal complexes displayed antibacterial and antifungal activities against the tested organisms. According to Tweedy's chelation theory [39], these data support the notion that metal ions enhance the antibacterial and antifungal activities by increasing lipophilicity, thus facilitating the penetration of metal complex across the cell membrane $[39,40]$. We tested the inhibitory concentration $50 \%\left(\mathrm{IC}_{50}\right)$ of the germaniu$\mathrm{m}(\mathrm{IV})$ complex with human hepatocellular carcinoma (HepG-2) cells (Table 7). The $\mathrm{IC}_{50}$ was higher than $1000 \mu \mathrm{g} /$ $\mathrm{mL}$, indicating that the germanium(IV) complex has a significant efficiency against the HepG-2 cell line.

\section{Conclusions}

The metal chelation between Ga(III), Ge(IV), and Hf(IV) metal ions with folic acid with $1: 2$ molar ratio was prepared. The folic acid acts as a tridentate chelate via oxygen and nitrogen atoms of carboxylate and amido groups. The formulas of the synthesized folate complexes were $\mathrm{NH}_{4}\left[\mathrm{Ga}(\mathrm{FA})_{2}\right] \cdot 4 \mathrm{H}_{2} \mathrm{O}, \quad\left[\mathrm{Ge}(\mathrm{FA})_{2}\right] \cdot 3 \mathrm{H}_{2} \mathrm{O}$, and $\left[\mathrm{Hf}(\mathrm{FA})_{2}\right] \cdot$ $3 \mathrm{H}_{2} \mathrm{O}$. These complexes have been discussed and assigned according to the microanalytical, conductance, FTIR, UVVis, ${ }^{1} \mathrm{HNMR}$, and TGA analyses. The thermal stability behavior of the synthesized folate complexes was confirmed as dependent on the calculation of kinetic thermodynamic parameters. The biological efficiency of the synthesized folate complexes was screened against bacteria and fungi species with significant values. The experimental $\mathrm{IC}_{50}$ data of the germanium(IV) complex in vitro showed the readiness of the Ge(IV) complex to be used as an antihepatocellular anticancer drug.

\section{Data Availability}

The data associated with this study can be accessed from the first author upon a reasonable request.

\section{Disclosure}

No funding was obtained for the study.

\section{Conflicts of Interest}

The authors declare that they have no conflicts of interest. 


\section{Acknowledgments}

The author is grateful to "Princess Nourah Bint Abdulrahman University" for supporting this research through the sabbatical leave program.

\section{Supplementary Materials}

Supplementary files included in the manuscript are ${ }^{1} \mathrm{HNMR}$ spectra of the $\mathrm{FAH}_{2}$-free ligand (Figure 1S), Ga(III) complex (Figure $2 \mathrm{~S}$ ), and $\mathrm{Ge}(\mathrm{IV})$ complex (Figure $3 \mathrm{~S}$ ) in DMSO- $\mathrm{d}_{6}$. (Supplementary Materials)

\section{References}

[1] E. Hamed, M. S. Attia, and K. Bassiouny, "Synthesis, Spectroscopic and thermal characterization of copper (II) and iron (III) complexes of folic acid and their absorption efficiency in the blood," Bioinorganic Chemistry and Applications, vol. 2009, pp. 1-6, Article ID 979680, 2009.

[2] A. Crowley, The generation of novel metal-folate-phenanthroline complexes and phenanthroline-folate conjugates with potential as chemotherapeutic agents, Ph.D. thesis, Technological University Dublin, Dublin, Ireland, 2019.

[3] S. Ruggeri, L. T. Vahteristo, A. Aguzzi, P. Finglas, and E. Carnovale, "Determination of folate vitamers in food and in Italian reference diet by high-performance liquid chromatography," Journal of Chromatography A, vol. 855, no. 1, pp. 237-245, 1999.

[4] I. P. Pogribny, A. G. Basnakian, B. J. Miller, N. G. Lopatina, L. A. Poirier, and S. J. James, "Breaks in genomic DNA and within the p53 gene are associated with hypomethylation in livers of folate/methyl-deficient rats," Cancer Research, vol. 55, no. 9, pp. 1894-1901, 1995.

[5] I. P. Pogribny, B. J. Miller, and S. J. James, "Alterations in hepatic p53 gene methylation patterns during tumor progression with folate/methyl deficiency in the rat," Cancer Letters, vol. 115, no. 1, pp. 31-38, 1997.

[6] E. Wainfan and L. A. Poirier, "Methyl groups in carcinogenesis: effects on DNA methylation and gene expression," Cancer Research, vol. 52, no. 7, pp. 2071s-2077s, 1992.

[7] S. A. J. Humadi, F. H. A. Al-Jeboori, K. K. Hammud, T. A. Mussa, and A. A. Alwan, "Synthesis and characterization of $\mathrm{Cu}$ (I)-Folic acid complex A theoretical and experimental study," Baghdad Science Journal, vol. 13, no. 2, pp. 121-127, 2016.

[8] R. Akkaya, "Biophysical and computational comparison on the binding affinity of important proteins of folic acid and its metal complexes," Cumhuriyet Medical Journal, vol. 41, no. 4, pp. 685-690, 2019.

[9] N. Ngernyuang, W. Seubwai, S. Daduang, P. Boonsiri, T. Limpaiboon, and J. Daduang, "Targeted delivery of 5fluorouracil to cholangiocarcinoma cells using folic acid as a targeting agent," Materials Science \& Engineering C-Materials for Biological Applications, vol. 60, pp. 411-415, 2016.

[10] C. Chen, J. Ke, X. E. Zhou et al., "Structural basis for molecular recognition of folic acid by folate receptors," Nature, vol. 500, no. 7463, pp. 486-489, 2013.

[11] X. Wang, J. Li, Y. Wang et al., "Enhances specific delivery of paclitaxel to folate receptor-positive tumours," American Chemical Society Nano, vol. 3, no. 10, pp. 3165-3174, 2009.

[12] Y. Wang, Y. Wang, J. Xiang, and K. Yao, "Target-specific cellular uptake of taxol-loaded heparin-PEG-folate nanoparticles," Biomacromolecules, vol. 11, no. 12, pp. 3531-3538, 2010.

[13] H. S. Yoo and T. G. Park, "Folate-receptor-targeted delivery of doxorubicin nano-aggregates stabilized by doxorubicin-PEGfolate conjugate," Journal of Controlled Release, vol. 100, no. 2 , pp. 247-256, 2004.

[14] W. Kaim, B. Schwederski, O. Heilmann, and F. M. Hornung, "Coordination compounds of pteridine, alloxazine and flavin ligands: structures and properties," Coordination Chemistry Reviews, vol. 182, no. 1, pp. 323-342, 1999.

[15] S. A. A. Sajadi, "Metal ion-binding properties of L-glutamic acid and L-aspartic acid, a comparative investigation," Natural Sciences, vol. 2, no. 2, pp. 85-90, 2010.

[16] M. G. A. El-Wahed, M. S. Refat, and S. M. El-Megharbel, "Synthesis, spectroscopic and thermal characterization of some transition metal complexes of folic acid," Spectrochimica Acta Part A Molecular Biomolecules Spectroscopy, vol. 70, no. 4, pp. 916-922, 2008.

[17] N. A. Skorik, "D-Metal folates and the folic acid-imidazole conjugate," Russian Journal of Inorganic Chemistry, vol. 60, no. 11, pp. 1402-1406, 2015.

[18] M. S. Refat, S. M. El-Megharbel, M. I. Kobeasy et al., "Synthesis, spectroscopic characterizations and biological activities of vanadyl (II) folate compound as a new anti-DNA damage and antioxidant agent," Journal of Molecular Liquids, vol. 220, pp. 468-477, 2016.

[19] P. R. Dametto, B. Ambrozini, F. J. Caires, V. P. Franzini, and M. Ionashiro, "Synthesis, characterization and thermal behaviour of solid-state compounds of folates with some bivalent transition metals ions," Journal of Thermal Analysis and Calorimetry, vol. 115, no. 1, pp. 161-166, 2014.

[20] L. Rojo, S. Radley-Searle, M. Fernandez-Gutierrez et al., "The synthesis and characterisation of strontium and calcium folates with potential osteogenic activity," Journal of Materials Chemistry B, vol. 3, no. 13, pp. 2708-2713, 2015.

[21] J. Nagaj, P. Kolkowska, A. Bykowska, U. K. Komarnicka, A. Kyziol, and M. Jezowska-Bojczuk, "Interaction of methotrexate, an anticancer agent, with copper (II) ions: coordination pattern, DNA-cleaving properties and cytotoxic studies," Medicinal Chemistry Research, vol. 24, pp. 115-123, 2015.

[22] C. Xi, Z. Liu, L. Kong, X. Hu, and S. Liu, "Effects of interaction of folic acid with uranium (VI) and basic triphenylmethane dyes on resonance Rayleigh scattering spectra and their analytical applications," Analytica Chimica Acta, vol. 613, no. 1, pp. 83-90, 2008.

[23] A. W. Bauer, W. A. Kirby, C. Sherris, and M. Turck, "Antibiotic susceptibility testing by a standardized single disc method," American Journal of Clinical Pathology, vol. 45, no. 4, pp. 493-496, 1996.

[24] T. Mosmann, "Rapid colorimetric assay for cellular growth and survival: application to proliferation and cytotoxicity assays," Journal of Immunological Methods, vol. 65, no. 1-2, pp. 55-63, 1983.

[25] S. M. Gomha, S. M. Riyadh, E. A. Mahmmoud, and M. M. Elaasser, "Synthesis and anticancer activities of thiazoles, 1,3-thiazines, and thiazolidine using chitosan-graftedpoly (vinylpyridine) as basic catalyst," Heterocycles, vol. 91, no. 6, pp. 1227-1243, 2015.

[26] A. A. El-Habeeb and M. S. Refat, "Synthesis, structure interpretation, antimicrobial and anticancer studies of tranexamic acid complexes towards Ga (III), W (VI), Y (III) and Si (IV) metal ions," Journal of Molecular Structure, vol. 1175, pp. 65-72, 2019. 
[27] M. A. Mesubi, "An infrared study of zinc, cadmium, and lead salts of some fatty acids," Journal of Molecular Structure, vol. 81, pp. 61-71, 1982.

[28] G. B. Deacon and R. J. Phillips, "Relationships between the carbon-oxygen stretching frequencies of carboxylato complexes and the type of carboxylate coordination," Coordination Chemistry Reviews, vol. 33, no. 3, pp. 227-250, 1980.

[29] A. M. Naglah, M. S. Refat, M. A. Al-Oma, M. Abhat, H. M. AlKahtani, and A. S. Al-Wasidi, "Synthesis of a vanadyl (IV) folate complex for the treatment of diabetes: spectroscopic, structural, and biological characterization," Drug Design, Development and Therapy, vol. 13, pp. 1409-1420, 2019.

[30] A. E. Fazary, Y.-H. Ju, A. Q. Rajhi et al., "Bioactivities of novel metal complexes involving B vitamins and Glycine," Open Chemistry, vol. 14, no. 1, pp. 287-298, 2016.

[31] K. Nakamoto, Infrared and Raman Spectra of Inorganic and Coordination Compounds, Wiley and Sons, Hoboken, USA, 3rd edition, 1978.

[32] G. D. Fasman, Handbook of Biochemistry and Molecular Biology, Volume-1 Nucleic Acids, pp. 65-215, CRC Press, Boca Raton, FL, USA, 1975.

[33] R. H. Holm and F. A. Cotton, "Spectral investigations of metal complexes of $\beta$-diketones. I. nuclear magnetic resonance and ultraviolet spectra of acetylacetonates," Journal of American Chemical Society, vol. 80, no. 21, pp. 5658-5663, 1958.

[34] F. A. Cotton and G. Wilkinson, Advanced Inorganic Chemistry, Interscience Publisher, Geneva, Switzerland, 1145 pages, 3rd edition, 1972.

[35] C. Bonechi, A. Donati, R. Lampariello et al., "Solution structure of folic acid molecular mechanics and NMR investigation," Spectrochimica Acta Part A, vol. 60, no. 7, pp. 1411-1419, 2004.

[36] H. H. Horowitz and G. Metzger, "A new analysis of thermogravimetric traces," Analytical Chemistry, vol. 35, no. 10, pp. 1464-1468, 1963.

[37] A. W. Coats and J. P. Redfern, "Kinetic parameters from thermogravimetric data," Nature, vol. 201, pp. 68-69, 1964.

[38] A. M. Beagan, T. Aouak, L. A. AlJuhaiman, A. M. Alodainy, W. S. Saeed, and M. O. Smane, "Poly (2-hydroxyethylmethacrylate-co-2-folate ethylmethacrylate) and folic acid/Poly (2-hydroxyethylmethacrylate) solid solution: preparation and drug release investigation," Journal PolymerPlastics Technology and Engineering, vol. 56, no. 18, pp. 1997-2018, 2017.

[39] B. G. Tweedy, "Plant extracts with metal ions as potential antimicrobial agents," Phytopathology, vol. 55, pp. 910-914, 1964.

[40] N. Dharmaraj, P. Viswanathamurthi, and K. Natarajan, "Ruthenium (II) complexes containing bidentate Schiff bases and their antifungal activity," Transition Metal Chemistry, vol. 26, pp. 105-109, 2001. 